\title{
Domestic Resource Taxation Makes One Solution to the Rare Earth Dispute in WTO
}

\section{-Insights into China's Resource Taxation}

\section{Rujia Chen}

Financial and Management Institute, Sichuan University of Arts and Science, Dazhou, China

Email: 543362338@qq.com

How to cite this paper: Chen, R.J. (2020) Domestic Resource Taxation Makes One Solution to the Rare Earth Dispute in WTO. Open Access Library Journal, 7: e6327.

https://doi.org/10.4236/oalib.1106327

Received: April 16, 2020

Accepted: May 5, 2020

Published: May 8, 2020

Copyright $\odot 2020$ by author(s) and Open Access Library Inc.

This work is licensed under the Creative Commons Attribution International License (CC BY 4.0).

http://creativecommons.org/licenses/by/4.0/

\begin{abstract}
Only one year after the WTO ruled against China on the raw material dispute, the United States, the European Union and Japan sued China in respect of China's restrictions on rare earth export. According to the non-discrimination principle of WTO, if China continues those export restrictions, it has to carry out restrictions on domestic rare earth users as well. The objective of this paper is to examine the justifiability of resource taxation as a way for the Chinese government to control domestic production and consumption of rare earth. The first part provides a general idea of the demand and supply sides in the world's rare earth market. Secondly, reasons to utilize resource taxation are given and western countries' resource taxation systems are analyzed. The third part is a closer look at current China's resource taxation system, problems with this system are viewed, and suggestions for the upcoming resource taxation reform could be made in the fourth part.
\end{abstract}

\section{Subject Areas}

International Trade

\section{Keywords}

World Trade Organization (WTO), Rare Earth, Non-Tariff Barrier, Non-Discrimination Principle, Resource Taxation

\section{Background Information}

According to the report of the US Geological Survey (USGS) [1], the rare earth is a group of seventeen elements with atomic numbers 57 through 71, plus scandium (21) and yttrium (39). The various application of rare earth, including high 
technology consumer products, environmentally friendly products, industrial and medical devices and national defense systems [2], makes it an essential raw material to most countries and many industries.

The latest data of rare earth reserves by country that can be retrieved online is the one published by the USGS report (2019) [3] shown in Table 1.

\subsection{The Demand Side on the World Rare Earth Market}

According to the released data from China-ASEAN Rare Earth Industry Development Forum, the global demand for rare earth in 2018 is around 190,000 tons. The number in 2011 was around 120,000 tons. Currently China consumes around $60 \%$ of the global rare earth consumption per year. Followed by Japan, the percentage is around $20 \%$, the US consumes $9 \%$, the EU 7\%, other countries $4 \%[4]$.

With a recovering world economy, worldwide expanding investment and the indispensability of rare earth in the high technology industry, the demand for rare earth is expected to increase in the following years.

\subsection{The Main Supply Side on the World Rare Earth Market}

\subsubsection{China's Rare Earth Situation}

It can be observed from Table 1 that China indeed has a great amount of rare earth reserve. Meanwhile, we can see in Table 1 that China supplies most of the world rare earth as well.

China has long been in the first place of exporting rare earth. From 1985 to 2007 , it produced 124,800 tons of rare earth, which has met 95 percent of the world demand (including domestic demand) [5].

Table 1. Rare earth reserves by country.

\begin{tabular}{ccc} 
Country & Reserves $(t)$ & 2018 Production $(t)$ \\
Australia & $3,400,000$ & 20,000 \\
United States & $1,400,000$ & 15,000 \\
Brazil & $22,000,000$ & 1000 \\
China & $44,000,000$ & 120,000 \\
Vietnam & $22,000,000$ & 400 \\
India & $6,900,000$ & 1800 \\
Russia & $12,000,000$ & 1200 \\
Malaysia & 30,000 & 200 \\
Other Countries & & 170,000 \\
World Total & $120,000,000$ & N/A \\
\hline
\end{tabular}

Note. Date retrieved from USGS. 


\subsubsection{China's Export Regulations on Rare Earth}

Due to the serious environmental issues caused by production and exploiting of rare earth and to protect this kind of non-renewable natural resource, the Chinese government has carried our four main measures to control the production and export of rare earth including export tariff, export quota, export license and minimum export prices.

\subsection{Reasons behind the Lost Dispute}

In 2009, the United States and the European Union brought a lawsuit against China on restrictions of raw material export. In 2011, WTO sent out a report to its member countries saying that the restrictions China laid on the export of 9 kinds of raw materials were against WTO agreements. The next year, the US, EU and Japan sued China about its limitation on rare earth export based on almost the same reasons as the last case. Now, China has to face this new challenge from the demand side of rare earth, and it may provide a way for China to deal with the rare earth dispute by analyzing the reasons why China lost the raw material case.

\subsubsection{China's Promises on Reducing Export Barriers}

The main legal document agreed on by China when joined WTO is the Protocol on the Accession of the People's Republic of China [6] (hereinafter referred to as "Protocol"). In this Protocol, China had made promises on eliminating non-tariff barriers. Article 7 is "Non-Tariff Measures", by which the Chinese government promised to eliminate non-tariff measures in an agreed period- "China shall eliminate and shall not introduce, re-introduce or apply non-tariff measures that cannot be justified under the provisions of the WTO Agreement" [7].

China also made promise on reducing export tariff in the Protocol. Article 11 "Taxes and Charges Levied on Imports and Exports", paragraph 3 "China shall eliminate all taxes and charges applied to exports unless specifically provided for in Annex 6 of this Protocol" [8]. In Annex 6, there are 84 items including kinds of minerals but no rare earth element or rare earth products were listed in Annex 6.

Article 7 indicates that if China imposes non-tariff export barriers on rare earth and conducts no consultation with trade partners, then China breaks this promise made in the Protocol. The fact is that China indeed reduced export quota of rare earth. In 2010, export quota decreased by 39 percent [9] compared to last year. In 2011, the first batch of rare earth export quota was 14,446 tons [10], which is an 11.4 percent decrease compared with the first batch in 2010. There are other non-tariff restrictions as well-export licensing and minimum export prices are mentioned above. Those non-tariff measures taken by Chinese government not only break the Protocol but also break the Paragraph 1, Article XI of General Agreement on Tariffs and Trade (GATT), which stipulates that "No prohibitions or restrictions other than duties, taxes or other charges shall be instituted or maintained" [11].

Meanwhile, China has also introduced export tariff on rare earth, according to 
the notice [12] published by the Department of Customs of the Ministry of Finance of the People's Republic of China, in 2012, Chinese government carried out new export tariff of 25 percent on praseodymium, yttrium and praseodymium oxide; 15 percent new export tariff on neodymium, praseodymium and yttrium fluoride; 25 percent new export tariff on other compounds of lanthanum, praseodymium, neodymium, dysprosium, terbium and yttrium; 20 percent on Nd-Fe-B allo.

\subsubsection{Non-Discrimination Principle}

One of the most important principles of WTO is trade without discrimination [13], which consists of two aspects: most-favoured-nation (MFN) and national treatment. MFN stipulates that a country should not discriminate between its trading partners and should give them equally MFN status. National treatment says if a member country grants right, benefit of privilege to its own citizens, it must also grant those advantages to the citizens of other countries while they are in that state.

In the Protocol, Article 3 of Section (D), part 2 is "Non-discrimination" [14], which sets that foreign individuals and enterprises shall be given treatment no less favourable than the ones given to other individuals and enterprises in respect of the procurement of inputs for production and the prices supplied by national and sub-national authorities in areas of energy, factors of production and etc.

As a matter of fact, non-tariff barriers introduced by the Chinese government discriminate foreign users of rare earth from domestic users.

The above two reasons explain why China lost raw material.

\section{Resource Taxation as a Restriction on Domestic Users of Rare Earth}

\subsection{Reasons to Use Resource Taxation}

From the above analysis, it can be expected that China may have to give up or lower the non-tariff barrier on rare earth export eventually. The Chinese government may resort to domestic resource taxation as a solution to protect rare earth as well as reduce the export.

Firstly, the price of rare earth in China is unreasonably low. Resource taxation will help to ameliorate the price formation mechanism. Reasonable price of rare earth should be the reflection of production cost, taxation cost, social cost and profit. The production cost mainly reflects the degree of difficulty of exploitation and the labor cost. Social cost is the cost of the environment, like pollution to the environment, but in China, this part is not a burden on the suppliers but paid by the society, thus the price of rare earth does not show the social cost. The taxation cost is very low for Chinese rare earth enterprises compared with those of western countries since the Chinese government charges a low resource tax and the resource tax does not embody the scarcity of rare earth.

Secondly, domestic resource taxation makes no discrimination between for- 
eign users and domestic ones of rare earth. One important ground of appeal of the Chinese government to the raw material case is Article XX (General Exception) of GATT, but it was rejected by WTO because one condition of this Article- "restrictions on domestic production or consumption as well" [15], was not met. Thus China was considered that it has violated the non-discrimination principle. By utilizing rare earth resource taxation, China can meet this requirement and make rare earth an exception subjecting to export restrictions in the rare earth dispute.

Only until 2011, the Central People's Government of the People's Republic of China has come out with an official notice of pushing a sustainable and healthy development of rare earth industry. In this notice, the importance of protecting and scientific usage of rare earth was formally presented and resource taxation measure as a regulatory method was highlighted.

\subsection{Experience from Western Countries}

Resource taxation in western countries has a longer history than that in China. Around 1970s, after a series of oil crises, western scholars did plenty of studies on resource taxation mechanism. Slade developed a general method of assessing the effects of tax policies in exhaustible-resource industries [16]. Cairns discussed the fundamental problems of taxation-efficiency and equity also happened to resource taxation, and concluded that a variety of tax instruments should be employed towards exhaustible resources [17].

In general, western countries maintain three types of resource related taxes, they are called resource rents for most of the time: resource royalty, mineral resources rent tax and mining rights lease. First, resource royalty is a compulsory fee, regardless of whether the producing firm is profiting or not. The rate and calculation methods vary from country to country, while this rent makes a revenue base for governments. Second, mineral resources rent tax, also known as resources super profits tax, is a progressive tax on excessive profits. This rent is to facilitate the taxation equity and to courage producing firms to improve efficiency. Third, mining rights lease is normally calculated based on the occupied mining area, it reveals the relation between nation and the firm owners and is to encourage firms to reduce the use of the land.

Unlike most western countries, the US does not introduce national unified resource taxation but grants the power of collecting taxes to each state. In this way, local government is able to set a reasonable tax rate based on its own resource condition and circumstance. Until 2013, there are 38 states that have levied mining tax on mining industry [18].

Canada applies similar resource taxation system as the US, mining and mineral exploitation related taxes are collected by provinces. An outstanding figure of Canadian resource taxation is that it encourages mineral producing firms to conduct smelting and processing in the less developed area within a province. 
In 2010, Australia, as a country possesses the biggest reserves of many natural resources, started its resource taxation reform. In May that year, Australian government announced that it intended to levy Resources Super Profits Tax (RSPT) on all the enterprises that exploiting non-renewable resources at a rate of 40 percent of their profits, and this plan was to begin on July 1, 2012. Before the reform, every state of Australia had their own taxation rates, and the resource taxes were specific duty, that is, the tax was based on the production volume of resources. However, prices of natural resources, especially non-renewable ones are rising rapidly in recent years, which actually reduced the real tax rates to a large extent.

Due to the strong bargaining power of Australian resource enterprises, the Australian resource taxation reform was a highly controversial and really rough process. Finally, the Australian government made compromises: to lower the tax rates on iron ore and coal to 30 percent, higher the tax threshold and extend the RSPT to coal-bed methane projects.

Inspiration of resource taxation reform can be obtained from western countries. Obstacles encounter by western countries when altering taxation system can also be a lesson for the Chinese government.

\section{China's Current Resource Taxation}

Before 2011, there was no particular taxation item for rare earth in China, they were taxed under the item "other non-ferrous metal ores" at $3 \mathrm{CN}$ Yuan per ton. Started on April 4, 2011, tax for light rare earth ores was raised to $60 \mathrm{CN}$ Yuan per ton, tax for heavy rare earth ores rose to $30 \mathrm{CN}$ Yuan per ton. Even so, the taxation on rare earth is still unreasonably low compared with the rare earth prices.

\subsection{Taxation Authority and Tax Items}

The current total rare earth charges in China consist of resource tax, other general expenses including value added tax, corporate income tax and business tax and surcharges.

In more specific terms, authorities and items related to resource taxation are as follows. First, the State Administration of Taxation of the People's Republic of China (SAT) is in charge of the sales VAT of rare earth minerals. Second, the Local Taxation Bureau charges resource tax of rare earth, the individual income tax of mine owners, sales tax, stamp duty, cit construction tax and education supplementary tax and so forth. Third, Ministries and Commissions under the State Council are granted with tax collection power. The detailed information can be found in Table 2 .

The above three parts of resource taxation are collected based on relevant law and official stipulation, while there are some charges levied by counties and towns that have no legal grounds such as rare earth inspection fees, town and village management fees. 
Table 2. Taxes and charges collected by national ministries and commissions.

\begin{tabular}{|c|c|}
\hline Ministries \& Commissions & Tax and charge items \\
\hline $\begin{array}{l}\text { Ministry of Land and Resources of the People's } \\
\text { Republic of China }\end{array}$ & $\begin{array}{l}\text { mineral resource compensation; } \\
\text { fees for temporarily occupying an area }\end{array}$ \\
\hline $\begin{array}{l}\text { Ministry of Water Resources of the People's } \\
\text { Republic of China }\end{array}$ & $\begin{array}{l}\text { soil and water conservation tax; } \\
\text { soil and water erosion prevention tax }\end{array}$ \\
\hline $\begin{array}{l}\text { State Forestry Administration of the People's } \\
\text { Republic of China }\end{array}$ & forest vegetation recovery payments \\
\hline $\begin{array}{l}\text { Ministry of Environmental Protection of the } \\
\text { People's Republic of China }\end{array}$ & charges for disposing pollutants \\
\hline $\begin{array}{l}\text { State Administration for Industry \& Commerce } \\
\text { of the People's Republic of China }\end{array}$ & business administration charges \\
\hline
\end{tabular}

\subsection{Taxation Standards}

The production of rare earth contains two major parts-mining and processing, rare earth related taxation is also divided into two sections based on this production flow. The detailed taxation rates and fees are listed in Table 3.

\subsection{Problems with Current Resource Taxation Policy}

The above description gives us an approximate whole picture of the current resource taxation in China. This taxation system gives us an impression of confusion and complication. In order to come up with more reasonable suggestions for the reform of current China's resource taxation system, it is necessary to figure out the existing problems with the system.

\subsubsection{Taxation Items}

One of the most outstanding features of the current taxation system is the coexistence of taxes and fees. This phenomenon is common in China's taxation system, which is also a problem known as replacing taxes by charges. The local government faces the task of improving and protecting the environment, and local infrastructure construction, thus Chinese local fiscal departments levy various kinds of items of taxes or fees on rare earth producing firms. Some counties have imposed more than ten categories of charges. In this way, the resource tax basis for state taxation is eroded, the taxpayers' ability to pay national taxes is weakened.

From the point view of the rare earth enterprises and the public, the complex taxation system plus addled local fiscal charges makes them unwilling to pay, they question why those fees and taxes justify in terms of environment protection since some items share the similar purpose of taxation, and whether local governments levy unreasonable items to maximize their own benefits.

\subsubsection{Low Rare Earth Tax Rates}

The current resource tax on rare earth is too low. Crucial factors like the scarcity of rare earth, the damage to the nature when operate exploitation should be taken into consideration when formulating the resource tax rate. 
Table 3. Current taxation and fees levied on rare earth industry.

\begin{tabular}{ccc}
\hline Tax items & $\begin{array}{c}\text { Specific duty standard } \\
\text { (CN Yuan/T) }\end{array}$ & $\begin{array}{c}\text { Ad valorem tax standard } \\
\text { (Price * Tax rate) }\end{array}$ \\
\hline $\begin{array}{c}\text { Mining section } \\
\text { VAT }\end{array}$ & NA & Max. 56\% \\
Resource taxation & 30 (Heavy REE); & $17.0 \%$ \\
60 (Light REE) & NA \\
$\begin{array}{c}\text { Other taxation (collected by } \\
\text { local taxation bureau) }\end{array}$ & NA & \\
$\begin{array}{c}\text { Mineral resource compensation } \\
\text { Fees collected by Ministries \& } \\
\text { Commissions }\end{array}$ & NA & $9.6 \%$ \\
Processing section & NA & $4.0 \%$ \\
VAT & & $10.0 \%-15.0 \%$ \\
Corporate income tax & NA & $42.0 \%$ \\
\hline
\end{tabular}

Note. Ministry of Land and Resources of the People's Republic of China [19].

The effective way to reflect the scarcity of rare earth is to raise resource tax so that to increase the taxation cost of rare earth, and this taxation cost will make a considerable portion in the price formation of rare earth. As written above, the resource tax for light RRE ore is $60 \mathrm{CN}$ Yuan per ton, $30 \mathrm{CN}$ Yuan per ton of heavy REE ore, if we use 1:1200 as the proportion of the concentrate rare earth over the rude ore, we get the real resource tax on light rare earth is $72,000 \mathrm{CN}$ Yuan per ton and 36,000 CN Yuan per ton for heavy rare earth, which are still low compared to the rare earth prices.

The low rare earth tax rate also lacks consideration of environmental factor. The rare earth exploitation and procession not only create value but leave environmental issues. Through the last two decades of nearly unregulated rare earth mining and refining, communities across China now have to face a heavily polluted living environment, the Chinese government has spent billions of dollars to clean up the damages [1]. The low rare earth would not make ends meet for the government since a substantial fiscal income will be spent on environmental recovery and protection.

The serious consequences of low resource taxation can be that it not only cannot make an effective regulation on the domestic rare earth exploitation and consumption, but also the low tax rate actually stipulates the overexploitation of rare earth.

\subsubsection{Tax Calculation Method}

The current resource taxation utilizes the specific duty or unit tax, the tax of which is calculated based on the amount of rare earth. In particular, the tax basis only covers the amount that are sold or used by enterprises themselves, the inventory is not taxed [20]. 
The unit tax cuts down the connection that should exist between rare earth price and resource tax. The increase in rare earth price does not lift the collected taxes; the drop in rare earth price will not slash the tax either. More differential income should go to the government, as it has the de facto ownership over the land resources, while most stay in the rare earth enterprises. The unit tax characteristic again gives rare earth producing firms impetus to overexploit when the rare earth price is high.

\subsubsection{Ascription and Distribution of Taxation Income}

Rare earth resource tax is de facto a local tax in China. In present China's recourse system, only the offshore petroleum resource tax is collected and attributes to the central fiscal income, the rest resources taxes all go into local government. This local character of current resource taxation brings about two major consequences.

First, the more rare earth exploited, the more taxes revenue local government can gain. According to some fieldwork study, there are local governments that turn a blind eye to native rare earth enterprise wasteful and unauthorized mining in order to collect more rare earth taxes.

Second, resource taxation being collected by the local government hindered the central government from arranging efficient transfer payments. It was reported that in Ganzhou (Jiangxi Province), an underdeveloped city but is abundant with rare earth resources, local residents were crazy about stealing and poaching rare earth [21]. Ganzhou is just an example of many other similar cities and counties, those areas are abundant with rare earth resources, occupied with countless mines, mining and processing plants, but people there are struggling on the edge of "wen bao" (living with adequate food and clothing). This phenomenon seems to be grotesque-people living in areas with plenty of resources while they are in poverty, but it is true. Because government owns the resources, state-owned resource companies take away resources with low taxation costs, central government only dispenses "di bao" (subsistence allowance). As a result, local residents were left in poverty and desperation so that they decide to "share" the benefits of mining rare earth.

The ascription and distribution is critical in terms of reducing inequality in China, especially the rural area of China.

\section{Directions of Reform to China's Resource Taxation Policy}

Confronting with the domestic situation where rare earth resources are irrationally exploited and wasted, rare earth price formation mechanism does not function, and the pressure from the world market intending to force China to export as much as before at low price, the Chinese government is brewing to reform the resource taxation system.

The new resource taxation shall be an effective instrument to allocate resources and more important is to impose constraints on domestic production and consumption of rare earth. Only if Chinese government indeed regulates the 
domestic users of rare earth, should it not violate the non-discrimination principle of WTO and quote the Article XX of GATT as a convincing argument in the rare earth dispute The key direction of reform should be fully internalizing the environmental costs and embodying the scarcity of rare earth as costs into the price formation of rare earth, so that to restructure the profit composition of rare earth producing enterprises. With more fiscal income, central government is able to compensate the affected residents in the meantime.

\subsection{Streamline Local Charges on Rare Earth Resources}

The resource fees charged by local government should be integrated into the resource taxation. Local government has kinds of items levied on rare earth related activities, such as mining royalty, mineral resource management fee, mineral resource compensation and mine maintenance fee. To learn from the western countries, all the fees can be put under the same and uniform items like resource royalty. Moreover, the former way to collect resource royalty of local government should be altered. Local governments may no longer be the beneficiary of resource taxes, instead, they should act as an intermediary by collecting resource taxation then remit to central government. Since local government has more comprehensive knowledge of resource condition in that area, they shall be consulted when setting new resource royalty rate.

\subsection{From Unit Tax to Ad Valorem Tax}

In a foreseeable future, the market demand of rare earth will keep climbing, a unit tax that does not link the tax with product price is no longer effective. As the owner of rare earth resources, government should get benefits from the increasing price of rare earth as well, but with unit taxation, all the extra profits go into rare earth enterprises. Besides, due to the low unit tax, firms are able to export rare earth at low price, government can only apply export tariff or non-tariff barriers to raise export price to a normal level. In the end, those regulations on rare earth export became excuses for western countries to sue China in the WTO.

On the contrary, ad valorem tax would be a better choice. Ad valorem tax is calculated based on the profit, if the price of rare earth goes up, resource tax increase as well. Ad valorem tax also has the tax shifting effect that rare earth firms will shift the tax burden to the customers by increasing rare earth prices. As a result, the rare earth prices for both domestic and foreign users increase. Then the export regulations can be removed.

Apart from that, the inventory of rare earth should also be taken into account. The current resource tax is only levied on sold and firm self-consumed volume. New resource taxation may use the market price as taxation basis to calculate the actually exploited or produced rare earth.

\subsection{Structure of Resource Tax}

Three major aspects should be considered in the new resource taxation system. 
First, the right to use land and resources should be taxed equally across the country. A uniform tax like mining rights lease in the western country is to be introduced. Second, different tax rates shall be levied on differential income from rare earth production. Rare earth resources differ in quality and elements, some areas are abundant with high quality and scarcer rare earth elements, some only have rare earth that are not so scarce compared to the other elements. Taxation rates may vary accordingly. Not only the scarcity but also the degree of scarcity of rare earth shall be reflected in new resource taxation system. Third, resource tax rates should be linked to the recovery rate of rare earth enterprises. If the actual recovery rate of a company is lower than the national standard, a higher tax rate should be applied, a lower tax rate for companies exercise higher recovery rate. In this way, firms have motivation to improve their procession efficiency.

There are other factors like resource inter-generation compensation that cannot be neglected in forming new resource taxation system.

\subsection{Redistribution of Resource Taxation Income}

As it won't be easy to redistribute a cake, making changes to long existing ascription and distribution of the resource taxation revenue will be beset with difficulties. Complaints may come from rare earth industry and local government. For rare earth enterprises, their profit margins are squeezed. Now they have to pay a price for the environmental damage and more taxes for the rare earth resource. If they try to maintain the current profit margins, they will need to increase prices, while higher prices make them less competitive in the world rare earth market. For the local government, they will expect a fall in their fiscal income.

To cope with the possible obstructions, the new distribution of rare earth taxes should be in favor of rare earth industry and local government in other ways. A portion of the taxes can be used to establish a special fund to support the R\&D of rare earth enterprises in areas of improving the processing and utilization efficiency of rare earth in production. Central government can also sustain local governments in taking measures against environmental pollution by financing environment treatment projects.

In addition, the central government is able to allocate more transfer payments to the local people living in the areas that are polluted and occupied by mines and rare earth processing plants, so that to improve their living condition to a limited extend. But it should be highlighted that to make sure those transfer payments are handed out to the particular groups of residents, central government may also carry out monitoring mechanism in the implementation process.

\section{Conclusions}

In the past two decades, China has become a dominant, low-cost producer of rare earth due to the preferential policies of the Chinese government and lax en- 
vironmental standards. Policies are different now in China. As a developing country, China is transiting from an extensive economy to an intensive one. Due to environmental issues, China tried to make exports of non-renewable resources under control and has set up tariff and non-tariff barriers in the rare earth export. But those regulations were interpreted by some western observers as "part of complex web of Chinese government industrial policies that seek to promote the development of domestic industries deemed essential to economic modernization" [22].

China's restriction on the export of rare earth is a shock to the world market-the world supply of rare earth is expected to drop heavily and the price of rare earth is expected to increase. In face of the difficulties and risks in diversifying the supply chain of rare earth, the United States, Japan, and the European Union formally accused China of violating the provisions of WTO with respect to trade in the rare earth minerals in March 2012 [2].

By examining and comparing the restrictions carried out by the Chinese government with the provisions of the WTO and the Protocol agreed on by China when joining WTO, China may only have limited and insufficient arguments because of the lack of regulations on domestic consumption of rare earth.

To deal with the rare earth situation in China, experience can be gained by reviewing the measures taken by western countries in terms of regulating domestic users of rare earth.

It can be concluded that domestic resource taxation is a solution to the current dilemma for China. The ongoing resource taxation system is analyzed in this article, and four major problems were figured out which makes China's current resource taxation mechanism inefficient. Inspirations are gained by studying the resource taxation system of western countries.

The main directions for China to reform resource taxation system include integrating the miscellaneous resource fees charged by local government into a country level resource tax; abandoning unit taxation and introducing ad valorem tax; land and resources using right, disproportionate resource distribution across the country and recovery rate of rare earth companies should be taken into consideration when setting the resource tax structure; the resource taxation revenue should be redistributed so that the central government is able to arrange fair transfer payments.

To sum up, to carry out a new resource taxation system seems to be a feasible way to help China impose restrictions on domestic users of rare earth and at the same time, restrict rare earth export without being discriminative.

New legislation on natural resources was passed in 2019, and would be enforced in 2020, which is not discussed in this paper; further research may pay attention to the latest changes in policy.

\section{Conflicts of Interest}

The author declares no conflicts of interest regarding the publication of this paper. 


\section{References}

[1] Bradsher, K. (2013) China Tries to Clean Up Toxic Legacy of Its Rare Earth Riches. http://cn.nytimes.com/china/20131023/c23earth/dual

[2] Giacalone, J.A. and Greenidge, G. (2013) China, the World Trade Organization, and the Market for Rare Earth Minerals. International Business \& Economics Research Journal, 12, 257-264. https://doi.org/10.19030/iber.v12i3.7669

[3] The United States Geological Survey (n.d.) The USGS 2019 Resources and Reserves. https://www.sciencebase.gov

[4] Chen, J.B., Huo, W.M., Li, X.F. and Wu, T. (2020) Comparative Analysis of Rare Earth Resources Situation between China, the US and the EU.

[5] Ma, R.Z. (2012) The Current Situation and Outlook of China Rare Earth Industry. China Science and Technology Industry, No. 8, 70-74.

[6] World Trade Organization (2001) Protocol on the Accession of the People's Republic of China (WT/L/432).

[7] World Trade Organization (2001) Protocol on the Accession of the People's Republic of China (WT/L/432). Article 7, 5.

[8] World Trade Organization (2001) Protocol on the Accession of the People's Republic of China (WT/L/432). Article 11, 7.

[9] China, Department of Foreign Trade (2010) Notice of the First Batch of Rare Earth Export Quota of 2011. Ministry of Commerce of the People's Republic of China. http://wms.mofcom.gov.cn/article/zcfb/g/201012/20101207335316.shtml

[10] China, Ministry of Commerce of the People's Republic of China (2009) Notice of the First Batch of General Trade and Rare Earth Export Quota of 2010. http://www.mofcom.gov.cn/article/b/g/201002/20100206792299.shtml

[11] (1986) General Agreement on Tariffs and Trade. Geneva. Article XI, 17.

[12] China, Department of Customs (2011) The Notice of Implementation of 2012 Tariff Plan. Ministry of Finance of the People's Republic of China, No. 27. http://gss.mof.gov.cn/zhengwuxinxi/zhengcefabu/201112/t20111215_615749.html

[13] World Trade Organization. Principles of the Trading System. http://www.wto.org/english/thewto_e/whatis_e/tif_e/fact2_e.htm

[14] World Trade Organization (2001) Protocol on the Accession of the People's Republic of China (WT/L/432). Part 2, 4.

[15] (1986) General Agreement on Tariffs and Trade. Geneva. Article XX, 37.

[16] Sladee, M. (1986) Taxation of Non-Renewable Resources at Various Stages of Production. The Canadian Journal of Economics, 19, 281-297. https://doi.org/10.2307/135285

[17] Cairns, R.D. (1985) Reform of Exhaustible Resource Taxation. Canadian Public Policy, University of Toronto Press, 11, 649-658. https://doi.org/10.2307/3550295

[18] InfoMine (2013) State/Provincial Mining Taxes for US and Canada. https://costs.infomine.com/

[19] Ministry of Land and Resources of the People's Republic of China (2010) The Basis and Standard of Collecting Mineral Resource Compensation. http://www.mnr.gov.cn/gk/bzgf/201003/t20100331_1971702.html

[20] Ma, Y.W. (2009) The Study on the Theory and Policy of China's Resource Reform. People's Publishing House, Beijing.

[21] Government Officials and Residents of Ganzhou Are Insanely Stealing Rare Earth: 
Even More Addictive than Heroin (2012).

http://haiwai.people.com.cn/n/2012/0417/c232580-16949089.html

[22] Morrison, W.M. and Tang, R. (2012) China's Rare Earth Industry and Export Regime: Economic and Trade Implications for the United States. Congressional Research Service. 